\title{
Systematic revision of a Miocene sperm whale from Patagonia, Argentina, and the phylogenetic signal of tympano-periotic bones in Physeteroidea
}

\author{
Florencia Paolucci, Mónica R. Buono, Marta S. Fernández, and José Cuitiño \\ Acta Palaeontologica Polonica 66 (1), 2021: 63-76 doi:https://doi.org/10.4202/app.00763.2020
}

Sperm whales (Physeteroidea) include today only two genera of morphologically disparate odontocetes: the largest toothed whale known (Physeter macrocephalus) and small sized forms (Kogia spp.). In contrast, their fossil record indicates a high diversity for the group during the Miocene, with over 20 species recognized. Miocene marine sediments from Patagonia (Argentina) record this diversity, including at least five species. Among them, Preaulophyseter gualichensis, from the Miocene of Gran Bajo del Gualicho Formation, has been one of the most enigmatic. Despite the fragmentary nature of the type and referred materials (isolated teeth and periotics), which casts some doubts on its validity, this species has not been revised since its original description. In this contribution, we re-describe the materials referred to $P$. gualichensis, revise the taxonomic status of the species and evaluate the phylogenetic signal of ear bones among Physeteroidea. Our results indicate that the physeteroid tympano-periotic complex morphology is poorly diagnostic at the species level. Intraspecific variation (including ontogeny and sexual dimorphism) and/or taphonomic processes cannot be ruled out as the causes of the minor differences observed among specimens. We suggest that sperm whale tympano-periotics retain many plesiomorphic characters and are diagnostic only between kogiids and non-kogiid physeteroids. Based on the fragmentary and isolated state of the studied specimens, and the lack of diagnostic characters in both teeth and periotics, we consider $P$. gualichensis as nomen dubium and we re-assign the referred specimens as Physeteroidea indet. A conservative morphology of the tympano-periotic and, to a lesser extent, the nasal complex in sperm whales, might result from the morpho-functional constraints imposed by a highly specialized but successful echolocation system.

Key words: Mammalia, Physeteroidea,Preaulophyseter gualichensis, Miocene, Patagonia, Argentina.

Florencia Paolucci [paolucciflorencia@fcnym.unlp.edu.ar, paolucciflor@gmail.com

] and Marta S. Fernández [martafer@fcnym.unlp.edu.ar],

CONICET-División Paleontología Vertebrados, Unidades de

Investigación, Anexo Museo, Facultad de Ciencias Naturales y Museo,

Universidad Nacional de La Plata, La Plata, Buenos Aires, Argentina.

Mónica R. Buono [buono@cenpat-conicet.gob.ar] and José Cuitiño [jcuitino@cenpat-conicet.gob.ar], Instituto Patagónico de Geología y Paleontología, CCT CONICET-CENPAT, Puerto Madryn, Chubut, 
Argentina.

This is an open-access article distributed under the terms of the Creative Commons Attribution License (for details please see creativecommons.org), which permits unrestricted use, distribution, and reproduction in any medium, provided the original author and source are credited.

Forif Full text $(1,285.3 \mathrm{kB})$ ।

FOF 